\title{
Seroepidemiological survey of chlamydial genital infections in Khartoum, Sudan
}

\author{
El-FADIL E OMER,* T FORSEY, † S DAROUGAR,† M H ALI, $\neq$ AND \\ H A El-NAEEM $\S$ \\ From the *Department of Medical Sciences, Um Al-Qura University, Makkah Al-Mukarramah, Sudan, \\ the + Subdepartment of Virology, Institute of Ophthalmology, University of London, London, the \\ $\ddagger$ Medical Research Council, Khartoum, and the §Department of Obstetrics and Gynaecology, Faculty of \\ Medicine, Khartoum, Sudan
}

SUMMARY A total of 494 patients (90 men and 404 women) attending a sexually transmitted diseases (STDs) clinic in Khartoum, Sudan, were-studied to assess the prevalence of chlamydial genital infections. Antibodies to Chlamydia trachomatis serotypes $\mathrm{D}$ to $\mathrm{K}$ were found in four $(4 \cdot 4 \%)$ men and $42(10 \cdot 4 \%)$ women, and $10(2 \cdot 5 \%)$ women had antibodies to serotypes $A$ to $C$.

\section{Introduction}

Studies in Khartoum have shown that gonorrhoea affects almost $26 \%$ of men and $4 \%$ of women patients attending a sexually transmitted disease (STD) clinic and that non-gonococcal urethritis (NGU) is the most common STD in men. ${ }^{12}$ The prevalence of chlamydial genital infections is unknown, but studies from elsewhere in Africa have suggested that they are as common there as in Europe and the United States. In Ethiopia 32\% of men and $45 \%$ of women patients with STD were found to have been infected with Chlamydia trachomatis genital serotypes. ${ }^{3}$ In Nigeria the rates were $19 \%$ in men and $27 \%$ in women patients with STD. ${ }^{4}$

In this study we have attempted to assess the prevalence of chlamydial genital infections by undertaking a seroepidemiological survey of patients attending an STD clinic in Khartoum, Sudan.

\section{Patients and methods}

We examined 494 consecutive patients attending an STD clinic in Khartoum with various genitourinary symptoms. Included were 90 men (aged 15 to 40 ), most of whom presented with urethritis, and 404 women (aged 16 to 65 ), who mainly presented with vaginal discharge.

Address for reprints: Dr El-Fadil E Omer, Department of Medical Sciences, Um Al-Qura University, Makkah Al-Mukarramah, Saudi Arabia

Accepted for publication 12 September 1984
We carried out laboratory tests to detect Neisseria gonorrhoeae, Trichomonas vaginalis, and Candida albicans, urine tests for defining urethritis, and the Venereal Disease Research Laboratory (VDRL) test to detect treponemal antibodies in Khartoum as described previously. ${ }^{1}$

Whole blood taken by finger prick, urethral discharge from men, and cervical discharge from women were collected on cellulose sponges. ${ }^{5}$ Specimens were stored at $4^{\circ} \mathrm{C}$ and sent to the London laboratory by post, where they were tested for the presence of antichlamydial antibodies by a microimmunofluorescence test using pooled antigens. ${ }^{6}$ Serum was examined at starting dilutions of $1 / 16$ for antichlamydial IgG and 1/8 for IgM. Genital discharge was tested for specific antichlamydial IgG and $\operatorname{IgA}$ at a starting dilution of 1/8.

\section{Results}

Table I shows the clinical and laboratory diagnoses of STDs in all patients based on clinical signs and laboratory tests carried out in Khartoum. Table II shows that antibodies specific for $C$ trachomatis serotypes $D$ to $K$ were found in four $(4 \cdot 4 \%)$ of 90 men and $42(10 \cdot 4 \%)$ of 404 women. An additional 10 women had serum IgG antibodies to $C$ trachomatis serotypes $\mathrm{A}$ to $\mathrm{C}$.

The titres of antibodies detected were generally low. The four men who were seropositive had serum IgG antibodies at a titre of $1 / 16$. In the women the geometric mean titre of serum IgG was $1 / 26$, although two women had titres of $1 / 128$ and four had titres of $1 / 256$. 
TABLE I Diagnoses of patients attending a sexually transmitted disease clinic in Khartoum

\begin{tabular}{lcc}
\hline Diagnosis & $\begin{array}{l}\text { No (\%) of } \\
\text { men }\end{array}$ & $\begin{array}{l}\text { No (\%) of } \\
\text { women }\end{array}$ \\
\hline Trichomoniasis or candidiasis & 0 & $211(52 \cdot 2)$ \\
Gonorrhoea & $33(36 \cdot 7)$ & $31(7 \cdot 7)$ \\
Non-gonococcal urethritis & $29(32 \cdot 2)$ & 0 \\
Lymphogranuloma venereum & $2(2 \cdot 2)$ & 0 \\
Syphilis (VDRL test positive) & $2(2 \cdot 2)$ & $10(2 \cdot 5)$ \\
Others & $10(11 \cdot 1)$ & 0 \\
No diagnosis & $14(15 \cdot 6)$ & $152(37 \cdot 6)$ \\
Total & 90 & 404 \\
\hline
\end{tabular}

Of the 46 patients in whom antibodies were detected, $38(83 \%)$ were aged between 20 and 49, most being between 20 and 29 years old. No patient had antibodies specific for lymphogranuloma venereum (LGV) serotypes of $C$ trachomatis or high titres of broadly cross reactive antibodies, which would have suggested infection with LGV. No antibodies to $C$ psittaci types were detected in the serum of any patient.

TABLE II Prevalence of antibodies to Chlamydia trachomatis serotypes $D$ to $K$ in 494 patients attending an STD clinic in Khartoum

\begin{tabular}{lc}
\hline $\begin{array}{l}\text { Source and type of } \\
\text { antichlamydial antibody }\end{array}$ & No (\%) positive/No tested \\
\hline Men: & $4 / 90(4 \cdot 4)^{*}$ \\
Serum IgG & $0 / 90$ \\
Serum IgM & $0 / 90$ \\
Urethral IgG or IgA & \\
Women: & $42 / 404(10 \cdot 4)^{*}$ \\
Serum IgG & $3 / 404(0 \cdot 7)$ \\
Serum IgM & $7 / 343(2 \cdot 0)$ \\
Cervical IgG or IgA & \\
\hline
\end{tabular}

${ }^{*}$ Geometric mean of titres of serum IgG: men 1/16; women 1/26.

\section{Discussion}

The prevalence of gonococcal infections was high in men patients $(36.7 \%)$ but much lower in women $(7 \cdot 7 \%)$, as found in previous reports from Khartoum (men $25 \cdot 9 \%$, women $3 \cdot 8 \%$ ). ${ }^{12}$ These findings may reflect the social conditions prevailing in that city. Although prostitution is technically illegal, Taha et al noted that almost half the men presenting with an STD had acquired their infection from prostitutes. ${ }^{1}$ Thus it would appear that whereas men with gonorrhoea present for treatment this is not true of the women and there must remain a reservoir of undetected gonococcal infections in the female population. Most $(52 \cdot 2 \%)$ of the women presenting at the clinic were found to be suffering from candidiasis and trichomoniasis.

The prevalence of infection with $C$ trachomatis serotypes D to K (genital pathogens ${ }^{7}$ ) was low in the patients presenting with STDs in Khartoum $(4 \cdot 4 \%$ in men and $10.4 \%$ in women). These figures are much lower than those found elsewhere in Africa; in Ethiopia the prevalence was $32 \%$ in men and $45 \%$ in women, ${ }^{3}$ and in Nigeria the figures were $19 \%$ in men and $27 \%$ in women. ${ }^{4}$ The titres of antichlamydial antibodies detected in Sudanese patients were also much lower than those found in other studies. The geometric mean titre of serum IgG was $1 / 16$ in men and 1/26 in women in Khartoum compared with $1 / 138$ and $1 / 193$ in Ethiopia and 1/37 and 1/71 in Nigeria.

It is odd that there should be such a difference between the prevalence of gonococcal and chlamydial infections in Khartoum, at least in men. Elsewhere $C$ trachomatis has been found as a concurrent infection in many patients with gonorrhoea. It is possible that, in Khartoum, chlamydial infections are mild, and patients would therefore not have a great incentive to attend a clinic for treatment. Antibiotics are freely available in Khartoum, and self medication may play a part in the low prevalence of chlamydial infections and account for the low antibody titres found.

Ten women in Khartoum had antibodies to $C$ trachomatis serotypes A to $\mathrm{C}$. Although these serotypes are usually associated with trachoma, they can occasionally cause genital infections. ${ }^{8}$ Three of the 10 women with these antibodies had gonorrhoea. Trachoma is endemic in Sudan but is usually mild and is not very common (Jones BR, personal communication). The interaction of trachoma with genital chlamydial infections in communities is not known. A study in Iran, however, showed a low prevalence of chlamydial genital infections $(16 \%)$ in men patients with STD who lived in an urban area. In surrounding rural areas, where trachoma is highly prevalent, no evidence of chlamydial genital infections was found. ${ }^{9}$

The prevalence of clinical LGV also appeared to be low in Khartoum. Only $3 \%$ of men had clinical signs of this disease and in no patient (male or female) were antibodies detected that suggested infection with LGV agents.

Nearly $40 \%$ of women and $18 \%$ of men presenting at the STD clinic in Khartoum had no apparent infection, and $31.7 \%$ of men patients had nongonococcal urethritis. Our results suggest that very few of these patients were infected by chlamydiae, leaving a large proportion of cases aetiologically undefined.

STD in Khartoum obviously poses a public health problem that requires adequate control and management. It will be interesting to observe whether chlamydial infections assume greater importance in the future, as has been the case in developed countries. 


\section{References}

1. Taha OMA, Ali MH, Omer EE, Ahmed MA, Abbard SA. Study of STDs in patients attending venereal disease clinics in Khartoum, Sudan. British Journal of Venereal Diseases 1979; 55:313-5.

2. Omer EE, Ali MH, Erwa H. Study of sexually transmitted disease in Sudanese women. Trop Doct 1980; 10:99-102.

3. Forsey T, Darougar S, Dines RJ, Wright DJM, Friedmann PS. Chlamydial genital infection in Addis Ababa, Ethiopia: a seroepidemiological survey. British Journal of Venereal Diseases 1982; 58:370-3.

4. Darougar S, Forsey T, Osoba AO, Dines RJ, Adelusi B, Coker GO. Chlamydial genital infection in Ibadan, Nigeria: seroepidemiological survey. British Journal of Venereal Diseases 1982; 58:366-9.
5. Treharne JD, Darougar S, Simmons PD, Thin RN. Rapid diagnosis of chlamydial infection of the cervix. British Journal of Venereal Diseases 1978; 54:403-8.

6. Treharne JD, Darougar S, Jones BR. Modification of the microimmunofluorescence test to provide a routine serodiagnostic test for chlamydial infection. J Clin Pathol 1977; 30: 510-7.

7. Dunlop EMC, Darougar S, Treharne JD. Epidemiology of infection by serotypes $\mathrm{D}$ to $\mathrm{K}$ of Chlamydia trachomatis. British Journal of Venereal Diseases 1980;56:163-8.

8. Jones BR. Prevention of blindness from trachoma. Trans Ophthalmol Soc UK 1975;95:16-33.

9. Darougar S, Jones BR, Cornell L, Treharne JD, Dwyer RStC, Aramesh B. Chlamydial urethral infection in Teheran: a study of male patients attending an STD clinic. British Journal of Venereal Diseases 1982; 58: 374-6. 